\title{
READERS
Insight
}

Journal of Management Info (JMI)

ISSN:2313-3376

www.readersinsight.net/jmi

Mh

\section{Impact of emotional intelligence and knowledge management on organizational performance: mediating role of organizational learning}

\author{
Hifza Mubeen ${ }^{1 *}$, Hira Ashraf ${ }^{2}$, Qasim Ali Nisar ${ }^{3}$ \\ ${ }^{1,2}$ Department of Management Sciences, University of Sargodha Gujranwala Pakistan \\ ${ }^{3}$ Othman Yeop Abdullah Graduate School of Business, University Utara Malaysia \\ * Corresponding author: hifzamubeen143@yahoo.com
}

\begin{abstract}
Due to globalization and uncertainty in business environment, organizations need to adapt and update their knowledge to remain competitive and innovative and to enhance their productive level. Moreover, Emotional intelligence is vital and accountable factor that determines victory in life. Such factors plays a significant part in workplace by influencing the collaboration between managers and employees. However, present study is undertaken to scrutinize the influence of emotional intelligence and knowledge management on the performance level of organization with mediating role of organizational learning. Current study is descriptive and cross-sectional. Sample size is 150 and simple random sampling method is used. Questionnaire survey method was used. Structural Equation Modelling (SEM) is used to support and prove the hypotheses statistically. Results of study enlightened that there is significant positive relationship between emotional intelligence, and organizational performance. Moreover knowledge management is also significantly associated with organizational performance. Furthermore, findings revealed that organizational learning significantly and partially mediates the relationship between emotional intelligence and performance as well as knowledge management and organizational performance. So, emotional intelligence and knowledge are important inputs and organizational learning is the key practice, which enhances the performance and output of any organization.
\end{abstract}

\section{ARTICLE INFORMATION}

\author{
Received: 25 March 2016 \\ Revised: 25 June 2016 \\ Accepted: 25 August 2016
}

DOI:

http://dx.doi.org//10.31580/jmi.v11i1.57

Keywords: Emotional Intelligence, Knowledge Management, Organizational Learning, Organizational Performance

\section{Introduction}

Today, the organizations have become conscious about the importance of Knowledge and Knowledge Management. Nowadays, organizations considered the Knowledge Management as the most important asset of the organization. Its proper utilization and application grant victory against the competitors. Furthermore, at the time of need the Knowledge Management environment provides the foundation to make best decision by delivering the significant and relevant information. The Knowledge Management systems avoid the duplication of effort and saves time. Knowledge management is about to create learning environment that supports knowledge acquisition, its transformation and application in the organization (Nonaka et al., 2001). Moreover, the term acquisition is to transfer the property rights.

Emotional Intelligence stated that having an aptitude to identify and comprehend the emotions and their impact on behaviour and attitudes. Similarly, people with excessive degree of emotional intelligence can recognize their own emotions and the emotions of other people whom they come in interaction. In the business world, the Emotional Intelligence is going to become even more essential in the future than it is today. Moreover, today's business world demand open communication, cooperation, collaboration, and a mutual respect among employees and their supervisor. As the economy is characterized by scare labor, it is most important for an organization to hold the good employees at workplace. On the other hand if an employee feels that, they aren't treated fairly at work can easily find employment elsewhere. So, an individual or a manager who possess the Emotional Intelligence can better understand and motivate the people they supervise. Furthermore, due to lack of Emotional Intelligence the manager can't understand the feelings and emotion of their employees and creates negative impact on the environment of organization.

In essence, the Organizational Learning is an effective tool as is continuously process and develop the organization's ability to counter the internal and external changes and challenges. Earlier, the researchers have been stated that diverse nature of organizational learning literature creates misunderstanding (Bontis et al., 2002). This research provides the better understanding of the concepts of organizational learning with contribution of Emotional Intelligence and Knowledge Management. It was suggested that through learning, people can arrive at new concepts that guide them to make effective decisions for suitable response and instant rectification of blunders (Argyris \& Schon, 1978). Organizational Learning deserves the systematic investigation (Spector \& Davidsen, 2006). Number of studies have been conducted on Knowledge Management, learning and performance of organization. But there is very little work to evaluate the impact of Emotional intelligence on Organizational Performance. So, current study is conducted to identify the impact of Emotional Intelligence on productivity. 
The purpose of current study is to scrutinize the relationship between Emotional Intelligence, Knowledge and organizational performance by considering the mediating role of Organization Learning.

This paper will answer following objectives:

1. To examine the relationship of Emotional intelligence and Organization performance:

2. To explore how Knowledge Management influence the Organizational Performance.

3. To identify the mediating role of organizational learning.

\section{Literature review}

\section{Knowledge management}

To gain the competitive advantage knowledge management is a vital source for any organization (Gold et al., 2001). It is enlightened that $\mathrm{KM}$, splitting from the word knowledge, and are about to improve the performance of the company, solve problems and to achieve organization's objectives (Ramachandran et al., 2009). However, it was proposed that knowledge acquisition is to upgrade the existing knowledge and produce new knowledge effectively (Choo \& Bontis, 2002). Knowledge acquirement is the component of $\mathrm{KM}$ that also influences the performance of organization. Furthermore, all those activities that are related to the application of knowledge in business to solve the problems create new or update the existing knowledge and adopt knowledge to new situation; such term is known as Knowledge utilization. In addition, organizations should assimilate the expert knowledge of many individuals (Gold et al., 2001). The effective application of knowledge is considered helpful to improve the organization performance, efficiency and to reduce cost (Davenport, 1998).

\section{Organizational learning}

Fredrick Taylor gave the concept of organizational learning as to transfer learning to the employees to enhance the performance and efficiency of organization in 1900. In this regard, Morgan \& Ramirez, (1984) suggest that Organizational learning is depending upon actual learning about to solve a common problem they encountered in their environment. Furthermore, learning practices provides the route map to achieve success, better performance and competitive advantage (Khandekar \& Sharma, 2006). Moreover, some managers consider that organizational learning is an uncertain investment that will provide mysterious results, while there is great variance between the productivity of the firms that hold organizational learning than other firms (Yeung et al., 2007). Similarly, Chiu \& Huang, (2013) stated in their study that due to globalization organizations are moving toward competitive zone, organizational learning is a major source that maximize the performance of organizations with a view to achieve competitive advantage and should be use effectively and efficiently. Moreover, learning programs gives useful outcomes and is also considered as strategic resource (Hannah \& Lester, 2009; Richey \& Autry, 2009; Dodgson, 1993).

\section{Organizational performance}

Organizational performance is an indicator to measure the quality and also provides the ways to achieve the organizational objectives (Hamon, 2003). Operational measures such as market share, sales growth, profit growth and financial measures as, ROE, ROI are frequently used to measure the organizational performance (Venkatraman \& Ramanujam, 1986). Similarly previous studies have also abstracted the performance of firm as the measurement of return on asset, turnover, growth, new product success (Narver \& Slater, 1990), profitability, sales growth and overall customer satisfaction (Ellinger et al., 2000), sales growth, market share and profitability (Deshpande et al., 1993), market share and overall performance (Jaworski et al., 1993), overall performance, new product success, change in relative market share (Baker\& Sinkula1999). In addition, Koh et al., (2007) used three standards to measure the organization's enactment, includes profitability (profit margin and capital return rate), organizational effectiveness (quality of product, success in product and aptitude of organization to retain their customers), growth and share of market (sales growth, and relative market share).

\section{Emotional intelligence}

Emotional intelligence is different from general intelligence, and is the part of social intelligence (Salovey \& Mayer, 1990). However, to motivate ourselves and managing the self-emotions and others emotional intelligence is the knack to identified our own and others feelings (Goleman, 1998). Furthermore, to manage the changes in business environment emotional intelligence plays a crucial role to help the managers and employees (Rafique et al., 2011). Goleman, (1995) organized these aptitudes into five magnitudes of emotional intelligence: self-awareness, self- regulations, self-motivation, social skills and social awareness. People who are emotionally intelligent are more self-aware about their limitations and strengths because they are more confident, flexible, innovative, and enthusiastic with new things (Bellack, 1999; Goleman, 1995, 1998; Mayer and Salovey, 1997; Mayers et al., 2004).

\section{Knowledge management and organizational performance}

The study indicated that there is positive relationship between knowledge management and organizational performance and knowledge management directly influence the performance of organization (Gholami, Asli et al. 2013). Moreover, researcher concluded that Knowledge management improves the organizational knowledge, knowledge related practices and performance of organizations (King, 2009). Similarly, Knowledge management significantly affect the performance, such as increase quality of products and services; and also enhance the efficiency and innovative ability (Maseki, 2012). likewise, relationship of Knowledge Management and Organizational Performance; there is significant and positive relationship between knowledge management and organizational performance (Fugate et al., 2009). As previous studies suggested that knowledge management significantly and positively related with the performance of any organization (Rasula, Vuksic et al., 2012).

\section{Mediating role of organizational learning}

The results of previous studies depicted that emotional intelligence is significantly and positively related with organizational learning. The Organizational Learning mediates the relationship between Knowledge Management and Organizational Performance and Knowledge Management and Organizational Learning have positive impact on the performance of organization (Jenatabadi, Hui et al., 2013) Furthermore, the employees that possess above average level of Emotional Intelligence and Organizational Learning such as innovations, execution of new ideas and structures are more than satisfactory. To create and maintain the organization learning such study provides implication for the management of people (Dissanayaka, Janadari et al. 2010). Furthermore, with the development of learning process correspondingly enhance the performance of organizations (King, 2009). Hence, the importance of organizational learning for the organizational performance as it is a process by which managers try to enhance the capabilities of organizational members to understand better and to accept the decision that enhance the organizational performance. Moreover, it is concluded that dogmatic literature considers the financial performance as organizational performance. Hence, any improvement, expansions and implementation of knowledge develops the organizational learnings (Peck et al., 2009). Hence, Nesan, (2004) argued that without effective knowledge learnings never happen. However, past studies has described that there is statistically strong, significant and positive relationship exists between organizational learning and performance(Hernaus \& Skerlavaj et al., 2008). Furthermore, KM creates effective impact upon organizational learning and organizational performance, and significant impact of organizational learning on organizational performance; organizational learning effectively mediates the relationship of Knowledge Management and Organizational Performance (Learning, 2014). 


\section{Emotional intelligence and organizational performance}

According to Tran (1998), emotional environment deeply influence the organizational dynamics such as creativity, idea generation, readiness and adoptability to change and provide assistance for learning processes and similarly influence the performance of organization as well as individual. Likewise, in previous studies it is indicated that emotional intelligence is the key factor for organizational performance and plays important role (Moghadam \& Jorfi et al.,2010). The past studies indicated that there is significant and optimistic impact of emotional intelligence on organizational performance.

\section{Emotional intelligence and organizational learning}

The emotional intelligence has positive effect on organizational learning with 99\% significant level (Saeidipour, Akbari et al., 2012). The findings of a study elaborated that the dimensions of emotional intelligence such as self-awareness, self-regulation self-motivation and social awareness have positively and significantly associated with organizational learning (Kazemi 2013). However, it is identified that emotional intelligence have significant relationship on the dimensions of organizational learning (Ezadinea, Fathi et al., 2011). In addition, the previous studies indicated that emotions and learning are meticulously related with each other (Damasio, 1994; Goleman, 1995). Further it is elaborated in another study (Rafiq et al., 2011), that there is positive and significant affiliation between emotional intelligence and organizational learning and stated that employees with emotional intelligence facilitate the organizational learning capacity. The number of studies was conducted on banking, education and manufacturing sector, researcher slightly ignore the medical sector for study. It would be more divers if researchers explore this area with appropriate sample size

\section{Knowledge management and organizational learning}

The past studies indicated that Knowledge Management and Organizational Learnings are significantly and positively correlated with each other (Hui, Jenatabadi et al., 2013). However, organizational learning can be enhanced by the escalation of Knowledge Management (Khammar \& Heidarzadegan et al., 2013). In essence, knowledge management and organizational learnings are significantly and positively correlated.

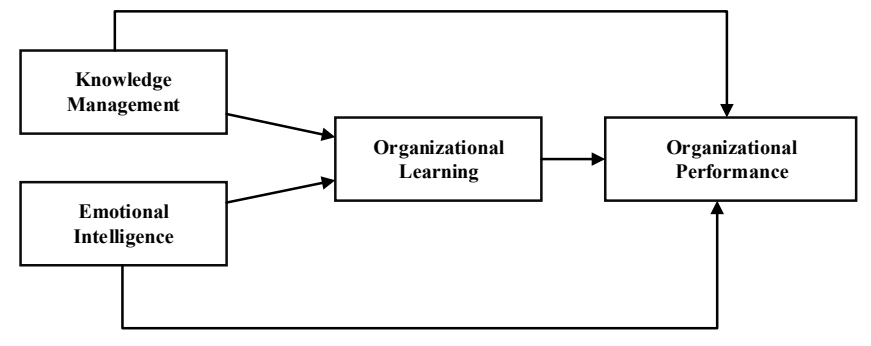

Fig.1. Theoretical Model

\section{Hypotheses development}

H1: Knowledge Management and Organizational Performance are significantly and positively correlated with each other.

H2: Organizational Learning significantly mediates the relationship between Emotional Intelligence and Organizational Performance. H3: Organizational Learning significantly mediates the relationship between Knowledge Management and Organizational Performance. H4: Emotional Intelligence positively and significantly affects the Organizational Performance.

Methodology
The purpose of current study is to investigate the affiliation of Knowledge Management and Emotional Intelligence on Organizational Performance. Furthermore, Organizational Learning mediated the relationship. The study is descriptive and quantitative in nature.

\section{Questionnaire design}

Questionnaire is used in survey. Questionnaire comprised of two sections. The first section is related to personal profile of respondents includes age, gender, education level, nature of employment and year of experience which is measured by nominal scale. The second section related to understudy variables such as Knowledge Management, Emotional Intelligence, Organizational Learning and Organizational Performance measured by 5-point Likert scale.

\section{Sampling}

The target population includes the employees of Pharmaceutical companies in Gujranwala. As for as sample size is concerned. Hair et al (2010) described a thumb rule that sample size can be obtained by multiplying the total items in a questionnaire by 10 . So, by following his methods, sample size for current study is 370 . Data has been collected by applying simple random sampling technique because most of the studies in social sciences adapted this technique.

\section{Data collection method}

Questionnaire survey method used to get the responses from targeted population. E-questionnaire also developed for the purpose of data collection.

\section{Measures}

All the scales used in the study adopted from previous research. Instrument consists of 37 items about the variables. To measure the Knowledge Management eight items scale is adopted (Al Mashari et al., 2002). To measure the Emotional Intelligence 16 items scale adopted (Brotheridge \& Lee, 1998). To measure Organizational Learning 10 items scale is adopted. To measure Organizational Performance 3 items scale is adopted (Nobbie and Brudney, 2003).

\section{Demographics}

Demographic section depicts the information about respondents' gender, age, and education level, nature of employment and length of service. We distributed 370 questionnaires to collect the responses of respondents. 85 filled by female and 285 filled by male respondents whose percentage is $22 \%$ and $78 \%$ respectively. Mostly respondents were between the age group of $26-45$ whose percentage is $50.7 \%$. Resulting to this $46.7 \%, 2.0 \%$ and $0.7 \%$ were age group of up to 25 , 46-55 and 50+ respectively. Furthermore respondents were $45.3 \%$, $46.0 \%, 4.95 \%$ and $3.75 \%$ belonged to Bachelors', Masters' $\mathrm{PhD}$. and others category of educational level respectively. Mostly respondents were highly educated with $46 \%$ Master degrees.

$54.0 \%, 28.7 \%$ and $17.3 \%$, respondents were doing their jobs as permanent employees, contractual employees and internees respectively. $45.3 \%$ respondents have up to 1 year length of service and $31.3 \%, 16.0 \%$ and $7.3 \%$ respondents have $2-5$ years, $5-10$ year and more than 10 years length of service at visited firms at Gujranwala.

\section{Results}

Following are the reuslts for current study.

Table 1: Mean and SD

\begin{tabular}{lccccccr}
\hline Const. & Mean & SD & $\mathbf{\alpha}$ & $\mathbf{1}$ & $\mathbf{2}$ & $\mathbf{3}$ & $\mathbf{4}$ \\
\hline $\mathrm{El}$ & 3.5080 & .74802 & 0.886 & & & & \\
$\mathrm{KM}$ & 3.7333 & .62452 & 0.790 & $.411^{* *}$ & & & \\
$\mathrm{OL}$ & 3.8254 & .57526 & 0.886 & $.399^{* *}$ & $.661^{* *}$ & & \\
$\mathrm{OP}$ & 3.6178 & .74624 & 0.742 & $.430^{* *}$ & $.336^{* *}$ & $.339^{* *}$ & 1 \\
\hline EI=Emotional Intelligence, & $\mathrm{KM}=$ Knowledge & \multicolumn{2}{c}{ Management, } \\
OL=Organizational Learning, OP=Organization Performance & &
\end{tabular}


The above-mentioned table is representing the descriptive statistics, reliability and Pearson correlation among all understudies variables. The highest correlation existed between knowledge management and organizational learning which is valued at .661. It is reflecting that knowledge management and organizational learning are positively related with each other with a moderate standard deviation. Other variables such as Emotional Intelligence and Organizational Performance are correlated with each other. There is significant and positive relationship exists by .430 . Emotional Intelligence and Organizational Learning are significant and positively correlated with each other by .399 . The above table indicated that Knowledge Management and Organizational Performance are significantly and positively correlated by 0.336 . The mean values are showing the trend of responses that most of them are laid towards agreeableness. Results indicate that alpha values for all variables are under acceptable range to prove data reliability.

Table 2: Factor Loadings

\begin{tabular}{|c|c|c|}
\hline Constructs & Items & Factor Loadings \\
\hline $\begin{array}{l}\text { Emotional } \\
\text { Intelligence }\end{array}$ & 16 & $\begin{array}{l}.781, .521, .786, .739, .705, .835, .708, \\
.813, .869, .865, .784, .818, .842, .711 \text {, } \\
.872, .759\end{array}$ \\
\hline $\begin{array}{l}\text { Knowledge } \\
\text { Management }\end{array}$ & 8 & $\begin{array}{l}.728, .892, .837, .763, .784, .857, .892 \text {, } \\
.741\end{array}$ \\
\hline $\begin{array}{l}\text { Organization } \\
\text { Learning }\end{array}$ & 10 & $\begin{array}{l}.761, .821, .786, .739, .745, .849, .732 \\
.712, .912, .892\end{array}$ \\
\hline $\begin{array}{l}\text { Organization } \\
\text { Performance }\end{array}$ & 3 & $.783, .902, .782$ \\
\hline
\end{tabular}

The value of factor loading shows that how much an instrument is correlated with main variable. The value of factor loading should be greater than $(0.7)$. The value of under study instrument are greater than 0.7 , it means that scale used in this study are valid.

Table 3: Psychometric Analysis

\begin{tabular}{lllllll}
\hline \multicolumn{1}{c}{ CR } & \multicolumn{1}{c}{ AVE } & \multicolumn{1}{c}{ El } & \multicolumn{1}{c}{ KM } & OL & OP \\
\hline El & 0.82 & 0.66 & $\mathbf{0 . 8 0 8}$ & & & \\
KM & 0.83 & 0.52 & 0.222 & $\mathbf{0 . 7 1 7}$ & & \\
OL & 0.84 & 0.691 & 0.23 & 0.381 & $\mathbf{0 . 8 2 1}$ & \\
OP & 0.81 & 0.63 & 0.465 & 0.229 & 0.271 & $\mathbf{0 . 8 0 9}$ \\
\hline
\end{tabular}

El=Emotional Intelligence, $\mathrm{KM}=$ Knowledge Management, OL=Organizational Learning, OP=Organization Performance

Table 3 representing results for psychometric analysis which indicates the discriminant and convergent validity of the model as the values of average variance extract (AVE)\& composite reliability (CR) are greater than 0.5 and 0.8 respectively so, this model has convergent validity. The value of discriminate validity depends upon the square root values of AVE which must be higher than the correlation values. Hence, the values of correlation are less than the values of square root of AVE so discriminant validity is also present in the model.

Table 4: Fit Indices for CFA \& SEM

\begin{tabular}{lll}
\hline Fit Indices & CFA & SEM \\
\hline Chi-square/df & 2.96 & 2.99 \\
GFI & 0.95 & 0.94 \\
AGFI & 0.82 & 0.81 \\
CFI & 0.94 & 0.93 \\
RMSEA & 0.05 & 0.06 \\
\hline
\end{tabular}

The results of model fitness from both confirmatory factor analysis (CFA) and structural equation model (SEM) dimensions shows in above table. The value of CFI indicates Comparative fit index is given at the first place which represents the variance covariance matrix and as its value is greater than 0.90 , in table 4 the value of CFI is 0.94 . so, it is declaring a good fit of the model. The value of adjusted goodness of fit index (AGFI) is 0.82 which is greater than 0.8 so, it is prove that model is good fit. GFI is representing the goodness-of-fit index and its given value lies in acceptable range. RMSEA is root mean square error of approximation whose value is lesser than 0.10 so that is also indicating the good fitness of model.

\begin{tabular}{lll}
\multicolumn{2}{l}{ Table 5: SEM Path Analysis } \\
$\begin{array}{l}\text { Independent } \\
\text { Variables }\end{array}$ & Effects & $\begin{array}{l}\text { Organizational } \\
\text { performance }\end{array}$ \\
\hline \multirow{3}{*}{ Emotional Intelligence } & Direct Effect & $.445^{*}$ \\
& Indirect Effect & $.362^{*}$ \\
& Total Effect & $.496^{*}$ \\
Knowledge & Direct Effect & $.397^{*}$ \\
Management & Indirect Effect & $.312^{*}$ \\
& Total Effect & $.442^{*}$ \\
\hline
\end{tabular}

Mediating variable: Organization Learning

The above-mentioned table depicted the path analysis of given variables and their relationships by using SEM. The value of direct and indirect effect elaborates the direction of relationship. The value of total effect $\left(0.496^{*}\right)$ is greater than the direct effect by $\left(0.445^{*}\right)$ for the relationship among emotional intelligence, organizational learning and organizational performance that shows the mediation effect. The coefficient value for mediation relationship, the total effect $(0.442 *)$ is greater than the direct effect by $\left(0.397^{*}\right)$ shows that organizational learning is a significant mediator between knowledge management and organizational performance.

\section{Discussion and conclusion}

The single-mindedness of current study is to find out the relationship between Emotional Intelligence, Knowledge Management and Organizational Performance and mediating role of Organizational Learning. Moreover, the findings showed that there is significant and positive relationship between Knowledge Management and Organizational Performance also support H1. As Knowledge Management improves the organizational knowledge, and significantly affect the performance of organization and also enhance the quality and effectiveness of products. The findings is consistent with the research by (Gholami, Asli et al., 2013; Rasula, Vuksic et al., 2012; Zaied \& Hussein et al., 2012). Furthermore, the findings divulged that Organizational Learning significantly and positively mediates the relationship of Emotional Intelligence and Organizational Performance also supported by H2. In addition employees posses high degree of emotional intellegence and have learning capabilities such as innovation and implication of new ideas to boost up the performance of organization. The results of the current study is consistent in line of research by (Jenatabadi, Hui et al., 2013; Dissanayaka \& Janadari et al., 2010; Kazemi, 2013). However, the results of enlightened that Organizational Learning significantly and positively mediates the relationship of Knowledge Management and Organizational Performance also supported by H3. In essence, with the development of learning process, Knowledge Management creates effective impact upon Organizational Performance. The results of current study are supported by the previous research by (Hui \& Jenatabadi et al., 2013; Khammar \& Heidarzadegan et al., 2013). Managers and employees whose posses the high degree of EI can do their jobs better, perfom well and productivity of organization will enhance. The emotion's knwoledge promotes the performance of organization. The results of previous studies by (Moghadam, Jorfi et al., 2010; Pelliteri, 2002), support the finding of current study.

\section{Practicle implications}

The pattern of Emotional Intelligence are not fixed so, by influencing the behaviour of employees the managers can achieve the organizational goals. However, with the application of Knowledge Management results in innovative efforts by the organization can enhance its productivity and can also promote the human resource management in the organization. Morever, when the knowledge of employees flourished, such excessive asset will creates the 
background for organizational learning to accomplish the organizational objectives further more, productivity of organization will boost up. Current study provides the insight to the managers how to maintain their degree of emotional intelligence and knowledge to achive the competitive gains.

\section{Limitations and future directions}

There are some limitations to this study that, the sample size is relative small due to time, georghaphical, financial and non financial constraints. The study can be more effective and accurate by increasing the sample size. Morever, simple random sampling is used. Future study can be expnaded increasing the sample size and adding the other variables to pridict the performance of organization. current study is cross-sectional, in future longitudinal studies can be done to compare findings and mixed approach can be used. For more generalized results the researcher can includes greater number of employees of different organization, different culture and context.

\section{References}

A. Peck, C. Gallucci, T. Sloan, and A. Lippincott, "Organizational learning and program renewal in teacher education: A sociocultural theory of learning, innovation and change," Educational Research Review, vol. 4, pp. 16-25, 2009.

AlMashari, M., Zairi, M. \&AlAthari, A. (2002). An empirical study of the impact of knowledge management on the organizational performance. Journal of Computer Information Systems, 42 (5), 74-82.

Argyris, Chris and Donald Schoen (1978). Organizational Learning: A Theory of Action Perspective. Reading, MA: Addison-Wesley.

Baker, W. E., and Sinkula, J. M. (1999) The Synergistic Effect of Market Orientation and Learning Orientation on Organizational Performance. Journal of the Academy of Marketing Science, 27(4), 411-427

Bellack JP. 1999. Emotional intelligence: a missing ingredient? Journal of Nursing Education 38(1): 3-4.

Bontis, N., Crossan, M.M. and Hulland, J., 2002. Managing an Organizational Learning System by Aligning Stocks and Flows. Journal of Management Studies, 39(4), pp.437-469

Brotheridge, C.M., \& Lee, R.T. (1998). On the dimensionality of emotional labour: Development and validation of the Emotional Labour Scale. Paper presented at the First Confrence on Emotions in Organizational Life, San Diego.

C. L. Yeung, K. Lai, and R. W. Y. Yee, "Organizational learning, innovativeness, and organizational performance: a qualitative investigation," International Journal of Production Research, vol. 45, pp. 2459-2477, 2007.

Chiu, L. J., \& Huang, N. T. N. A Study on the Relationships among the Organizational Learning Capacity, Organizational Learning Culture, and Organizational Innovation Performance.

Choo, C., Bontis, N.(2002): The Strategic Management of Intellectual Capital and Organizational Knowledge. Oxford University Press, New York. Cincinnati: South-Western.

Damasio AR. Descartes' error: emotion, reason, and the human brain. New York: G.P. Putnam; 1994

Desphande, J.U., Webster, F.E., 1993. Corporate culture, customer orientation, and innovativeness in Japanese firms: a quadric analysis. Journal of Marketing 57, 23-37.

Dissanayaka, D., et al. (2010). "Role of emotional intelligence in organizational learning: An empirical study based on banking sector in Sri Lanka."

Ellinger, A. E., Daugherty, P., \& Keller, S. (2000) The Relationship between Marketing/Logistics Interdepartmental Integration and Performance in U.S. Manufacturing Firms: An Empirical Study. Journal of Business Logistics, 21(1), 112-128

Ezadinea, N., et al. (2011). "Interdisciplinary journal of contemporary research in business."

Fugate, B. S., et al. (2009). "Linking improved knowledge management to operational and organizational performance." Journal of Operations Management 27(3): 247-264.

Gholami, M. H., et al. (2013). "Investigating the influence of knowledge management practices on organizational performance: an empirical study." Acta Polytechnica Hungarica 10(2): 205-216.

Gold, A.H., A. Malhotra and A.H. Segars, 2001. Knowledge management: An organizational capabilities perspective. Journal of Management Information Systems, 18(1): 185-214.
Goleman, D., 1995. Emotional intelligence: Why it can matter more than IQ. New York: Bantam Books.

Goleman, D., 1998. Working with emotional intelligence. New York: Bantam Books.

Hamon, T.T., 2003. Organizational effectiveness as explained by social structure in a faith-based business network organization. Regent University.

Hernaus, T., et al. (2008). "Relationship between organisational learning and organisational performance: The case of Croatia." Transformations in Business \& Economics 7(2): 32-48.

Hui, H., et al. (2013). Knowledge Management and Organizational Learning in Food Manufacturing Industry. International Conference on Economic, Finance and Management Outlooks (ICEFMO 2013). October 5-6 2013, Kuala Lumpur, Malaysia.

Jaworski, B. J., \& Kohli, Ajay K. (1993). Market orientation: Antecedents and consequences. Journal of Marketing, 57(3), 53-70.

Jenatabadi, H. S., et al. (2013) "Explore Linkage Between Knowledge Management And Organizational Performance In Asian Food Manufacturing Industry."

Kazemi, M. (2013). "A Study on Relationship between Emotional Intelligence and Organizational Learning." International Journal of Social Science Tomorrow 2.

Khammar, Z., et al. (2013). "The Relationship between Knowledge Management and Organizational Learning with the Effectiveness of Ordinary and Smart Secondary School Principals." International Journal of Education and Literacy Studies 1(1): 23-32.

Khandekar, A., \& Sharma, A. (2006). Organizational learning and performance understanding Indian scenario in present global context. Education+ Training,48(8/9), 682-692.

King, W. R. (2009). Knowledge management and organizational learning, Springer.

Koh, S. C. L., Demirbag, M., Bayraktar, E., Tatoglu, E., and Zaim, S. (2007) The Impact of Supply Chain Management Practices on Performance of SMEs. Industrial Management \& Data Systems, 107(1), 103-124

L. J. Nesan, "Efficacy-information for implementing learning in construction," The Learning Organization, vol. 11, pp. 45-66, 2004.

Learning, O. (2014). "The Effect Of Knowledge Management On Organizational Learning And Performance Of Education Department Of Abhar County." Management Review 3(12a).

M. Dodgson, "Organizational learning: a review of some literatures," Organization studies, vol. 14, pp. 375-394, 1993.

Maseki, C. (2012). Knowledge management and performance of commercial banks in Kenya, University of Nairobi.

Mayer JD, Salovey P. 1997. What is emotional intelligence? In Emotional Development and Emotional Intelligence: Educational Implications, Salovey P, Sluyter DJ (eds). Basic Books: New York.

Mayer, J.D., Salovey, P., \& Caruso, D.R. (2004). Emotional intelligence: Theory, findings, and implications. Psychological Inquiry, 15(3), 197-215.

Moghadam, S. K., et al. (2010). "Impact of Emotional Intelligence on Performance of Employees." Postmodern Openings(04): 63-74.

Morgan, G. and R. Ramirez, 1984. Action learning: A holographic metaphor for guiding social change. Human relations, 37(1): 1-27.

Narver, J. C., and Slater, S. F. (1990) The Effect of a Market Orientation on Business Profitability. The Journal of Marketing, 54(3), 20-35

Nobbie, P.D. and Brudney, J.L. (2003), "Testing the Implementation, Board Performance, and Organizational Effectiveness of the Policy Governance Model in Nonprofit Boards of Directors", Nonprofit and Voluntary Sector Quarterly, Vol. 32 No. 4, pp. 571-595.

Nonaka and D. J. Teece, Managing industrial knowledge: creation, transfer and utilization: Sage Publications Ltd, 2001.

Pellitteri J. 2002. The relationship between emotional intelligence and ego defence mechanism. Journal of Psychology 136(2): 182-194.

performance from

R. Richey and C. Autry, "Assessing interfirm collaboration/ technology investment tradeoffs: The effects of technological readiness and organizational learning," The International Journal of Logistics Management vol. 20, pp. 30-56, 2009.

Rafiq, M., Naseer, Z., \& Ali, B. (2011). Impact of Emotional Intelligence on Organizational Learning Capability . International Journal of Academic Research.. 3(4). 321-325.

Ramachandran, S.D., S.C. Chong and H. Ismail, 2009. The practice of knowledge management processes: A comparative study of public and private higher education institutions in Malaysia. VINE, 39(3): 203-222

Rasula, J., et al. (2012). "The impact of knowledge management on organisational performance." Economic and Business Review for Central and South-Eastern Europe 14(2): 147. 
S. T. Hannah and P. B. Lester, "A multilevel approach to building and leading learning organizations," The Leadership Quarterly, vol. 20, pp. 34-48, 2009.

Saeidipour, B., et al. (2012). "Study the effect of emotional intelligence on organizational learning staff, Case study: Jihad Agriculture Organization of Isfahan." Management Science Letters 2: 2501-2510.

Salovey, P. and J.D. Mayer, 1990. "Emotional intelligence", Imagination, Cognition and Personality, 9(3): 185-211.

Singh, S.K. (2007). Role of emotional intelligence in organizational learning: An empirical study. Singapore Management Review, 29(2), 55-74.

Spector, J. M., \& Davidsen, P. I. (2006). How can organizational learning be modeled and measured? Evaluation and Program Planning, 29(1), 63-69.
T.H Davenport and L. Prusak, Working knowledge: How organizations manage what they know: Harvard Business School Press, 1998.

Tran, V. (1998) 'The role of the emotional climate in learning organizations', The Learning Organisation,vol. 5, no. 2.

Venkatraman, N., Ramanujam, V., 1986. Measurement of business performance in strategy research: a comparison of approaches. Academy of Management Review 11 (4), 801-814.

Zaied, A. N. H., et al. (2012). "The role of knowledge management in enhancing organizational performance." International Journal of Information Engineering and Electronic Business (IJIEEB) 4(5): 27. 